New Approaches to Latin American History 
THIS PAGE INTENTIONALLY LEFT BLANK 


\title{
New Approaches to \\ Latin American History
}

\author{
edited by \\ RICHARD GRAHAM and PETER H. SMITH
}

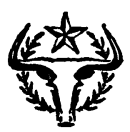

UNIVERSITY OF TEXAS PRESS, AUSTIN AND LONDON 
Library of Congress Cataloging in Publication Data

Graham, Richard, 1934-

New approaches to Latin American history.

Includes bibliographical references.

1. Latin America-Historiography-Addresses, essays, lectures. 2. Latin America-History-Addresses,

essays, lectures. I. Smith, Peter H., joint author.

II. Title.

F1409.7.G72 980'.007'2 74-2017

ISBN 0-292-75506-6

Copyright (C) 1974 by Richard Graham and Peter H. Smith All Rights Reserved

Printed in the United States of America

Composition by G\&S Typesetters, Austin

Printing by The University of Texas Printing Division, Austin

Binding by Universal Bookbindery, Inc., San Antonio 
TO

LEW IS H A K E 
THIS PAGE INTENTIONALLY LEFT BLANK 